\title{
Instrumental Learning and Sustainability Indicators: Outputs from Co- Construction Experiments in West African Biosphere Reserves
}

\author{
Harold Levrel $^{1}$ and Meriem Bouamrane $^{2}$
}

\begin{abstract}
Co-adaptive management of biodiversity is largely based on a collective learning process. This collective learning concerns "instrumental policy learning," "social policy learning," and "political learning." This paper focuses on instrumental policy learning that has been launched in four West African biosphere reserves. It is based on a MAB-UNESCO/UNEP-GEF programme concerning the coconstruction of interaction indicators (between development and conservation), inspired by the Integrated Natural Resource Management (INRM) methodology. Using this process, we were able to test conventional Pressure-State-Response indicators, highlight their limitations, and develop new indicators starting from stakeholders' stories and perceptions. These new indicators can also be tested through collective restitutions and simulations. We also discuss: a proposed framework for producing interaction indicators that are relevant to all stakeholders and enjoy a certain legitimacy; the importance of an ecosystem services approach to support discussions on biodiversity conservation; opportunities for using the indicators in an interactive, decentralized way at the ecosystem scale through simulation models; the costs of collecting, processing, and maintaining these interaction indicators, and how these costs may be offset using local knowledge.
\end{abstract}

Key Words: biosphere reserves; integrated natural resource management; interaction indicators; instrumental learning; local knowledge

\section{INTRODUCTION}

Over the last 15 years, adaptive co-management has become one of the most influential approaches for understanding and managing complex socialecological systems (Ostrom et al. 1994, Berkes and Folke 1998, Arrow et al. 2000, Lal et al. 2001, Gunderson and Holling 2002, Dietz et al. 2003, Kinzig et al. 2003, Olsson et al. 2004, Millennium Ecosystem Assessment 2005). "Adaptive comanagement" can be defined in many ways, but there are two basic criteria that any adaptive comanagement program should respect. First, the core value of learning-by-doing (learning by experimenting) processes (Holling 1978, Walters and Hilborn 1978). Second, a collaborative management aspect (Ostrom 1990, Pretty 1995, 2003) that involves multiple stakeholders and disciplines. To make a long story short, the "novelty of adaptive comanagement comes from combining the iterative learning dimension of adaptive management and the linkage dimension of collaborative management in which rights and responsibilities are jointly shared" (Resilience Alliance).
Learning-by-doing may concern (Table 1): areas of learning, such as instrumental policy learning, social policy learning, and political learning (May 1992); modes of learning, such as laboratory experimentation, adaptive management, trial and error, and unmonitored experience (Lee 1999); cycles of learning, such asincremental learning, lurching learning, and transformational learning (Gunderson et al. 1995).

In this paper, we study an instrumental policy learning that relates to interaction indicators, in an adaptive management way.

The "collaborative dimension" of this instrumental policy learning is inspired by the group modelbuilding methodology, which should facilitate team learning when system dynamics are used collectively (Vennix 1996). Indeed, system dynamicists have demonstrated that the group model-building process can lead to better understanding of the complex dynamics, for three main reasons (Rouwette et al. 2002): by capturing 
Table 1. Cycles, areas, and modes of learning

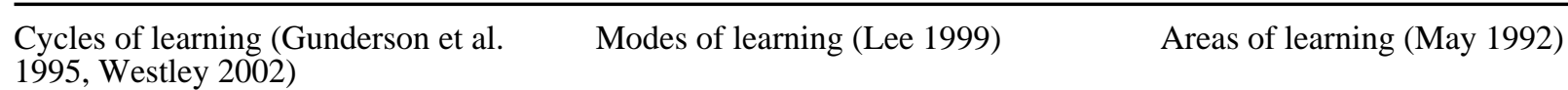

“Incremental learning occurs as plans, models, and policies are implemented and evaluated. Models or schemas are assumed to be correct, and learning is characterized by collecting data or information to update those models." (Gunderson et al. 2006)

"Episodic learning is discontinuous in time and space. It can be generated by ecological regime shifts that reveal the inadequacies of the underlying models or policies." (Gunderson et al. 2006)

"Transformational learning is the most profound form of learning. Cross-scale surprises or the emergence of novelty characterize this type of change. In these cases, learning requires the reframing of problem domains." (Gunderson et al. 2006)
“Laboratory experiments: controlled observation to infer cause; replicated to assure reliable knowledge; enabling prediction, design, control; theory (it works, but range of applicability may be narrow)." (Lee 1999)

“Adaptive management: systematic monitoring to detect surprise; integrated assessment to build system knowledge; informing model-building to structure debate; strong inference (but learning may not produce timely prediction or control)." (Lee 1999)

"Trial and error: problem-oriented observation; extended to analogous instances; to solve or mitigate particular problems; empirical knowledge (it works but may be inconsistent \& surprising)." (Lee 1999)

"Unmonitored experience: casual observation ; applied anecdotally; to identify plausible solutions to intractable problems; models of reality (test is political, not practical, feasibility)." (Lee 1999)
"Instrumental policy learning about the viability of specific instruments or programs." (Lal et al. 2001)

"Social policy learning about social constructions of policy problems, the scope of policy, or policy goals." (Lal et al. 2001)

"Political learning, during which stakeholders become more knowledgeable about policy process and negotiating skills." (Lal et al. 2001) knowledge diversity, facilitating appropriation of the results, and improving the individual learning process.

We begin by describing our case studies and presenting our methodological assumption. We then highlight our main results concerning diagnostic and co-construction sessions. Finally, we discuss the potential for implementing new interaction indicators.

\section{CASE STUDY: THE CO-CONSTRUCTION OF INTERACTION INDICATORS IN FOUR WEST AFRICAN BIOSPHERE RESERVES}

Agenda 21, adopted during the 1992 Earth Summit in Rio de Janeiro, set out the objectives to attain sustainable development, and divided them into 40 chapters. The $40^{\text {th }}$ and final chapter calls for the harmonization of efforts to allow the construction of sustainable development indicators: "Methods for assessing interactions between different sectoral environmental, demographic, social, and developmental parameters are not sufficiently developed or applied. Indicators of sustainable development need to be developed to provide solid bases for decisionmaking at all levels and to contribute to a selfregulating sustainability of integrated environment and development systems" (Commission on Sustainable Development 1992, 40.4). 


\section{Indicator}

One of the main advantages of indicators over other evaluation tools lies in the fact that they represent a boundary object. "Boundaries objects are objects which inhabit various communities of practices and satisfy the informational needs of each one. Thus they possess enough plasticity to adapt to local needs as well as to constraints imposed by those who use it, and enough robustness to maintain a common identity" (Bowker and Star 1999, pp. 297). Indicators facilitate collective discussion and enable stakeholders to estimate indirectly what would otherwise be too expensive to measure directly (Desrosières 2003).

An indicator can be considered as a plural object that may be defined according to its function, the tool it represents, and/or the method of construction used to develop it (Levrel 2006):

- The functional aspect-the function of an indicator is to provide concise sense-making information about a given phenomenon so that it is possible to communicate, understand, or take decisions about this phenomenon. The indicator has both a political and scientific function as a "tool of action" and a "tool of proof."

- The instrumental aspect — an indicator is an instrument composed of a synthesizing mechanism (aggregation, mean value, weighting...), making it possible to summarize a vast amount of information, and an interface (index, map, color...), allowing the release of signals containing the summarized information. In order to be effective, the indicator's form must be adapted to its function, as is true of any tool. Moreover, the form must be adapted to the capacities and representations of potential users so that the synthesized information contained in the signal may be easily extracted.

- The constructivist aspect-an indicator is a tool made by using a method that entails a social division of labor (data collectors, specialists, statisticians...) and a decisionmaking process (negotiation, mediation, dialogue, validation). It is the combination of these two components that leads to the adoption of conventions concerning the indicator (unit of measure, spatial scale of reference, synthesizing mechanism). Such conventions are both partial and biased; nevertheless, they may appear legitimate if the method is in line with the functions that are expected of the resulting indicator.

\section{Interaction Indicators}

The interaction indicators represent socially constructed tools whose purpose is to provide concise information about the way in which various phenomena have a reciprocal influence on one another, with the aim of communicating or taking decisions about such co-evolutions. If monitoring indicators provide the basis to follow some trends concerning parameters, interaction indicators must inform about the co-evolution between them.

In the sustainable development domain, interaction indicators address the question of the links between environmental problems, economical activities, and social well-being (Hukkinen 2003). At this point, we are particularly interested in the interactions between conservation and development issues. Among interaction indicators, the Pressure-StateResponse (PSR) indicators set up in the 1990s (Oorganisation for Economic Co-operation and Development (OECD) 1994; Fig. 1) are the most widely used. They allow an assessment of the pressure that human activities exert on the state of the environment, and identification of the social responses that will make it possible to offset the negative effects of such pressure. They were the model for the driving forces-pressure-state-impactresponse indicators of the European Environment Agency (EEA 2003), the driving forces-stateresponse indicators of the Commission on Sustainable Development (CSD 2001), and the pressure-state-use-response-capacity indicators of the United Nations Environment Programme, Convention on Biological Diversity (UNEP-CBD 2003).

\section{A UNESCO-MAB/UNEP-GEF Programme in Four West African Biosphere Reserves}

Working on the interactions between human activities and biodiversity is one of the approaches 
Fig. 1. The Pressure-State-Response (PSR) framework.

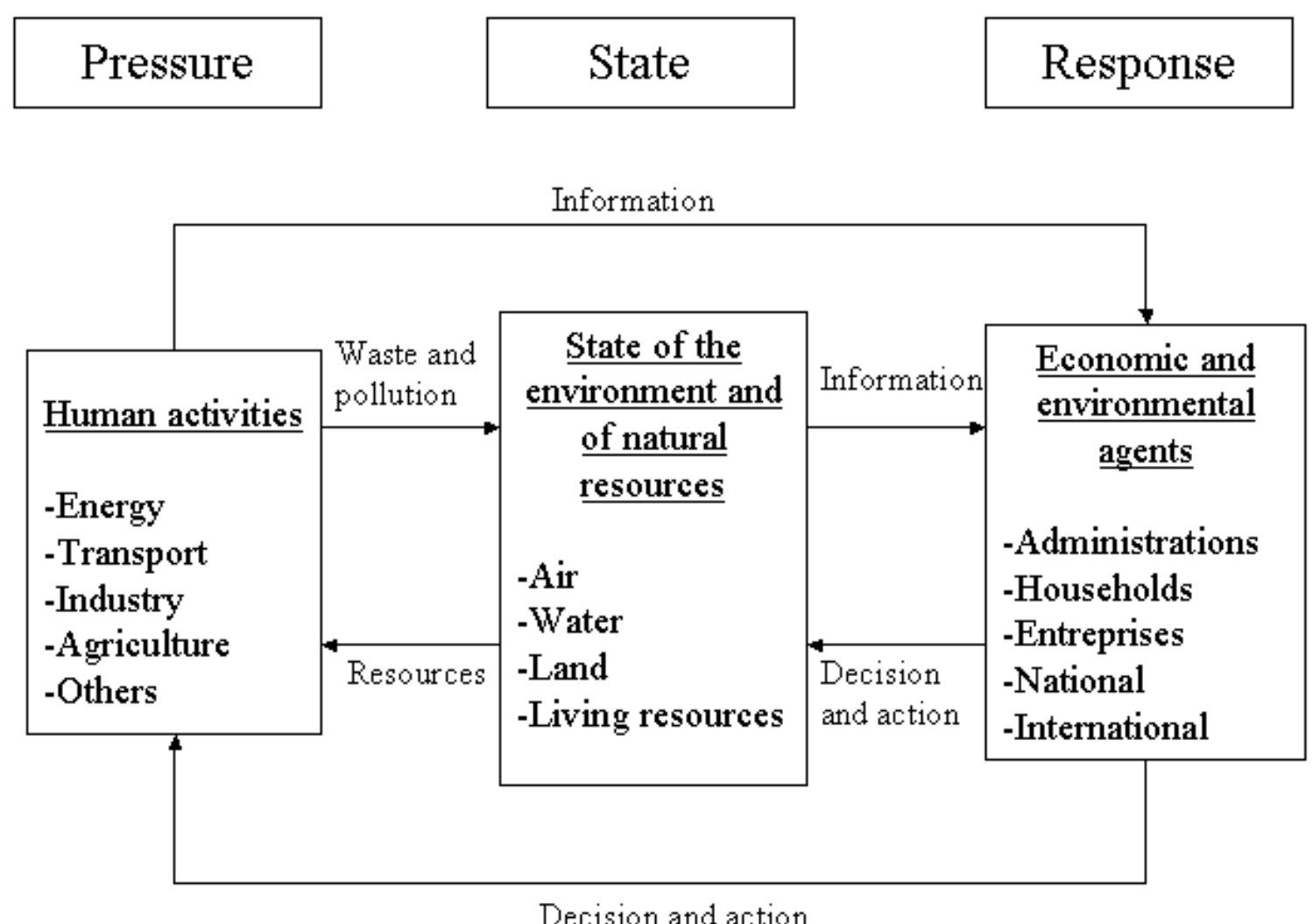

Source : OECD (1994)

adopted by UNESCO's intergovernmental Man And Biosphere (MAB) Programme, relying in particular on biosphere reserves-experimental sites where it is possible to test the relevance of tools regarding interactions between development and conservation. Within the framework of a regional program (UNESCO-MAB/United Nations Environment Programme-Global Environment Fund (UNEPGEF) Regional Project on "Building scientific and technical capacity for effective management and sustainable use of biodiversity in dryland biosphere reserves of West Africa") aiming to better understand the dynamic interactions between stakeholders and resources, new methodological approaches-based on mediation and local know how-were applied to test interaction indicators. This program integrated six West African biosphere reserves: Pendjari (Benin), Comoé (Ivory Coast), Boucle du Baoulé (Mali), W (Niger), Niokolo-Koba (Senegal), and Mare aux Hippopotames (BurkinaFaso).

The six biosphere reserves participating in the project are located in the West Sudano-Sahelian savanna biome and North Sudano-Guinean biome (Corresponding to the Udvardy Western Sahel biogeographical province and the West African woodland savanna province), which occupy a band 
across West Africa inland from the Guinean Forest biome (Table 2). Relatively high human population densities ( 50 to 100 persons $/ \mathrm{km}^{2}$ ) and a long history of human occupation characterize this region.

These six biosphere reserves share a common legacy in that they were first established solely as national parks. Buffer and transition zones were established as a second step. The establishment and management of the biosphere reserves have resulted in limited conservation successes as these sites are still mainly managed as national parks without effective collaboration with local communities. Local populations have been identified as essential in the management of the biosphere reserves but, at the same time, they are perceived by many as being a "management problem." As such, the reserve managers are challenged with balancing the resource demands of local communities with the conservation imperatives of the reserve management plans. In all six sites, the lack of communication and consultation between the various stakeholders living and working in the biosphere reserve makes it difficult to establish management plans that are supported by local communities.

These biosphere reserves face the same problem of biodiversity erosion due to unsustainable uses. Socioeconomic conditions, lack of access and clearly defined use-rights to natural resources have contributed to local communities compromising long-term environmental sustainability for the satisfaction of immediate needs, sometimes resulting in illegal exploitation of natural resources in the core areas. The pressures on the core area of the biosphere reserve are increasing as local communities exploit resources therein, given that they have few other viable livelihood options and fertile lands are scarce in areas surrounding the biosphere reserve. This longer-term threat to biodiversity within the six sites is compounded by the depletion of resources outside of the core areas, resulting in ever more pressure being placed on core and buffer zones as people seek available resources for their livelihoods.

This discussion focuses exclusively on four biosphere reserves, because we did not take part in the investigation conducted in Pendjari and Comoé.

\section{Interaction Indicators: for Whom and for What Reasons?}

The goal of the interaction indicators recommended by the MAB programme is to facilitate dialog among stakeholders regarding interactions between human activities and biodiversity. This means giving stakeholders the opportunity to coordinate their representations, interests, and opinionswhich may be conflicting-so they can work together toward development and conservation objectives and on the methods and tools used to reach such objectives.

This goal implies that interaction indicators are intended for all those concerned by the biosphere reserves-reserve managers, local populations, scientists-and should facilitate better communication among stakeholders when it comes to ecosystem services and human well-being, while also strengthening their technical and scientific capabilities through better access to information.

In light of these factors, an interaction indicator coconstruction process was suggested. It was based on an extended social division of labor, including representatives of local populations, biosphere reserve managers, scientists with backgrounds in natural and social sciences, and on a mediationbased process for making decisions.

Co-construction represents the technical dimension of the co-management and is a means of sharing knowledge and power, and finally, of fulfilling information disclosure (Lal et al. 2001, Olsson et al. 2004). In this approach, a decision support system (DSS) helps launch a collaborative planning process for investigating and testing in order to facilitate adaptive co-management (Briassoulis 2001, Lal et al., 2001, Bousquet et al. 2002, Gurung et al. 2006).

The development of a standardized protocol for coconstruction is necessary in order to compare interaction indicators in the four biosphere reserves.

\section{Methodological Assumptions Adapted to Established Objectives: How and by Whom?}

To define the theoretical and ethical foundations underlying the indicator co-construction process, assumptions were drawn up. 
Table 2. Characteristics of the biosphere reserves and period during which the co-construction has been carried out.

\begin{tabular}{|c|c|c|c|c|}
\hline & $\begin{array}{l}\text { Boucle du Baoulé } \\
\text { (Mali) }\end{array}$ & $\begin{array}{l}\text { W (the Niger } \\
\text { component of the } \\
\text { transboundary BR) }\end{array}$ & Niokolo-Koba (Senegal) & $\begin{array}{l}\text { Mare aux } \\
\text { Hippopotames (Burkina- } \\
\text { Faso) }\end{array}$ \\
\hline $\begin{array}{l}\text { Period of the co- } \\
\text { construction process }\end{array}$ & $\begin{array}{l}\text { 4-10 November } 2004 \\
\text { ( } 3 \text { days for the } \\
\text { diagnostic and } 3 \text { days } \\
\text { for the co- } \\
\text { construction) }\end{array}$ & $\begin{array}{l}\text { 14-23 October } 2004 \text { ( } 5 \\
\text { days for the diagnostic } \\
\text { and } 3 \text { days for the co- } \\
\text { construction) }\end{array}$ & $\begin{array}{l}27 \text { February-6 March } \\
2005 \text { ( } 4 \text { days for the } \\
\text { diagnostic and } 4 \text { days } \\
\text { for the co- } \\
\text { construction ) }\end{array}$ & $\begin{array}{l}\text { 1-5 October } 2004 \text { ( } 3 \\
\text { days for the diagnostic } \\
\text { and } 2 \text { days for the co- } \\
\text { construction) }\end{array}$ \\
\hline Date of creation & 1982 & 1996 & 1981 & 1977 \\
\hline Core area size & 533.037 ha & 220000 ha & - & 68000 ha \\
\hline Buffer area size & 177.345 ha & 77000 ha & - & 90000 ha \\
\hline Transition area size & 1.789.618 ha & 431000 ha & - & 28000 ha \\
\hline Total size & 2500000 ha & 728000 ha & 913000 ha & 186000 ha \\
\hline Location & $\begin{array}{l}\text { Located in the West } \\
\text { part of Mali, and } \\
\text { crosses the region of } \\
\text { Koulikoro and Kayes } \\
\left(13^{\circ} 10^{\prime} \text { to } 14^{\circ} 30^{\prime} \mathrm{N} ;\right. \\
\left.08^{\circ} 25^{\prime} \text { to } 09^{\circ} 50^{\prime} \mathrm{W}\right)\end{array}$ & $\begin{array}{l}\text { Situated in the } \\
\text { southwestern region of } \\
\text { Niger, the "W" region, } \\
\text { and lies in an ancient } \\
\text { peneplain with little } \\
\text { altitudinal variation } \\
\left(11^{\circ} 55^{\prime} \text { to } 13^{\circ} 20^{\prime} \mathrm{N} \text {; }\right. \\
\left.02^{\circ} 04^{\prime} \text { to } 03^{\circ} 20^{\prime} \mathrm{E}\right)\end{array}$ & $\begin{array}{l}\text { Situated on the River } \\
\text { Gambia, close to the } \\
\text { Guinean border in } \\
\text { southeastern Senegal } \\
\left(12^{\circ} 30^{\prime} \text { to } 13^{\circ} 20^{\prime} \mathrm{N} \text {; }\right. \\
\left.12^{\circ} 20^{\prime} \text { to } 13^{\circ} 35^{\prime}\right)\end{array}$ & $\begin{array}{l}\text { Located in Bobo- } \\
\text { Dioulasso District in the } \\
\text { west of the country, } 80 \\
\mathrm{~km} \text { north of the town of } \\
\text { Bobo-Dioulasso }\left(11^{\circ} 30^{\prime}\right. \\
\text { to } 11^{\circ} 45^{\prime} \mathrm{N} ; 04^{\circ} 05^{\prime} \text { to } \\
\left.04^{\circ} 12^{\prime} \mathrm{W}\right)\end{array}$ \\
\hline Ecosystem and habitats & $\begin{array}{l}\text { Wooded and bush } \\
\text { savanna, Butyrospermum } \\
\text { paradoxum savanna, } \\
\text { herbaceous steppes and } \\
\text { grasslands }\end{array}$ & $\begin{array}{l}\text { Gallery forests, } \\
\text { woodlands, scrublands, } \\
\text { grasslands }\end{array}$ & $\begin{array}{l}\text { Herbaceous savanna, } \\
\text { seasonally flooded } \\
\text { grassland, dry forest }\end{array}$ & $\begin{array}{l}\text { Open and gallery } \\
\text { forests, wetlands }\end{array}$ \\
\hline Status of fauna & Critical & $\begin{array}{l}\text { Abundance of higher } \\
\text { mammals (elephant, } \\
\text { buffalo, antelopes...) }\end{array}$ & $\begin{array}{l}\text { Recent decrease of } \\
\text { higher fauna }\end{array}$ & $\begin{array}{l}\text { Hippopotamus and } \\
\text { birds }\end{array}$ \\
\hline Main activities & $\begin{array}{l}\text { Agriculture and } \\
\text { livestock husbandry, } \\
\text { forestry, and crafts }\end{array}$ & $\begin{array}{l}\text { Agriculture, grazing } \\
\text { and goat raising }\end{array}$ & $\begin{array}{l}\text { Agriculture, pastoralism, } \\
\text { honey gathering and } \\
\text { craft activities }\end{array}$ & $\begin{array}{l}\text { Agriculture, livestock } \\
\text { husbandry, fishing, } \\
\text { hunting and plant } \\
\text { collecting }\end{array}$ \\
\hline $\begin{array}{l}\text { Specific driving-forces } \\
\text { on biodiversity }\end{array}$ & $\begin{array}{l}\text { Scarcity of watering } \\
\text { points creates } \\
\text { competition between } \\
\text { fauna and cattle. }\end{array}$ & $\begin{array}{l}\text { Lack of watering } \\
\text { points, increased } \\
\text { grazing in forest lands, } \\
\text { bush fires, and } \\
\text { poaching }\end{array}$ & $\begin{array}{l}\text { Banana plantations, } \\
\text { poaching, and } \\
\text { reduction of natural } \\
\text { habitat }\end{array}$ & $\begin{array}{l}\text { Poaching inside the } \\
\text { core area. Illegal } \\
\text { fishing, and wood } \\
\text { cutting. }\end{array}$ \\
\hline
\end{tabular}


The first assumption concerns the existence of a symmetry of ignorance (Arias and Fischer 2000). None of the stakeholders, as individuals or as a group, has enough knowledge to solve a problem or address an issue that is collective in nature. Knowledge is dispersed: in relationships, practices, institutions, expertise, and memory. In this context, scientific knowledge is complementary to traditional knowledge (Berkes and Folke 2002, Folke 2004). Therefore, it is necessary to set up a protocol to facilitate the "disclosure" of information as well as the involvement of all stakeholders, so that as many people as possible may benefit from dispersed knowledge and experience (Dietz et al. 2003). This point implies abandoning "expert methods" in favor of an approach that could be described as "technical democracy," which implies broad participation by local stakeholders in the indicator construction process (Callon et al. 2001).

Controversy is at the base of any democratic system. It is the same for the technical democracy. The controversy makes it possible to conceive and test projects and solutions that integrate a plurality of points of view. The dynamics of controversy encourage the participants to mobilize many arguments and counter-arguments, to clear up the point they wish cleared up, to justify and to refute assertions. Moreover, it leads to a series of negotiations, learning, and compromises concerning these interaction indicators, and makes them more relevant and more accurate.

However, although system dynamicists have proved that a group model-building process can improve understanding of the complex dynamics, such observations depend on two conditions (Vennix 1999, Callon et al. 2001). First, one should remember the characteristics of these processes and in particular how these groups build a common reality from their exchanges (conflicts of representation, negotiation, consensus). Second, neutral facilitators, or mediators, have to govern these exchanges using specific procedures in order to create a fair process and discourage defensive communication (Vennix 1999, Levrel et al., in press).

The second assumption is, therefore, that technical democracy is based on principles of equity and separation of powers, as is any democratic system. Participants must have more or less equal clout during exchanges, and no matter what happens, the approach must remain voluntary (Dietz et al. 2003).
In particular, participants should feel forced to reveal any information. Respecting these principles explains how it is possible to switch from individual knowledge to collective knowledge. Indeed, it is the belief in the reciprocity of information pooling that encourages agents to share their experiments and their specific knowledge. People participate in the hopes of acquiring new information. This belief depends on participants having confidence in the procedure that makes it possible to organize the debates, disclose information, and launch a collective instrumental learning process.

Therefore, the process must possess a certain "external" aspect, or neutrality, in the eyes of participants, so that it appears fair (Espeland and Stevens 1998). This "coming from outside" quality may be ensured by one or more mediators, who have been recognized as legitimate by all parties, and whose objective will be to elicit a structure for dialog (Weber 1996). The mediator represents a "judiciary order" and guarantees the separation of powers.

In addition, the co-construction process is coordinated in each West African country by an interaction indicator coordinator with experience in the field of indicators and by a UNESCO consultant who trains the local mediators to facilitate the coconstruction process of interaction indicators (Levrel 2004a, 2004b, 2004c, Levrel and Kane 2005). Mediators and coordinators have different functions. The mediators' main goal is to encourage dialog, whereas coordinators deal with the implementation of a common protocol to identify interaction indicators in every reserve. For each biosphere reserve, the work of co-construction is carried out in two phases over 1 week (Table 2, Append. 1). The first phase is a diagnostic period during which it is possible to question the relevancy of the existing indicators. The second phase corresponds to an instrumental learning period during which we develop new indicators through a participatory approach.

\section{RESULTING EFFECTS OF THE DIAGNOSTIC PHASE: REDEFINING PRESSURE AND RESPONSE INDICATORS}

\section{The Diagnostic Phase}

The diagnostic phase lasts 2-3 days, during which the coordinators approach representatives of local communities. Meetings take place with professional 
groups, interest groups, villages, park managers, and individual representatives (Table 3). The encounters also depend on subjective factors, such as geographical limitations, distance and time constraints, coordinator networks, or park manager networks, and, at times, pure chance.

The goal is to establish initial contact, present the objectives of the program, and begin discussions about interaction indicators. Discussions focus on issues relating to biodiversity access and use (in particular, identification of stakeholder resourcess, depletion of certain resources, conflicts over access or use, local communities' relations with biosphere reserve personnel, and so forth) in order to better comprehend the institutional and ecological situations in which stakeholders develop and evolve. During this first phase, the PSR indicators are questioned. Throughout our discussion, the state of ecosystem services, the origins of pressure, and the potential social response are dealt with keeping in mind the main problems highlighted by participants.

\section{Pressure Indicators}

Although participants routinely mention "pressure" as a cause of resource deterioration, such pressure never includes their own activities; it seems to be caused only by "other users" of resources. Users of the reserve often have a simplified view of the activities they do not carry out themselves, and which they consider to be a source of pressure, but they refute the idea that their activities might be considered in the same light.

The purpose of PSR indicators is not to allow participants to understand one another better, but rather to determine which activities constitute pressure, and to designate the people who are responsible for exerting this pressure, which can exacerbate tensions and certain conflicts. Moreover, pressure exerted on the environment is not always anthropogenic (e.g., invasive species such as Typha australisin the Mare aux Hippopotames or Sida cardifolia in the W Reserve). Furthermore, competition for resources, e.g., between wart hog, baboon or hippopotamus populations and the villages around biosphere reserve, causes a great deal of damage to the fields. Finally, some uses of biodiversity may help maintain or renew such biodiversity, thereby assisting nature. This happens, for example, when people build beehives, which results in an increase in the bee population, thus enabling the pollination of numerous plant species, or when human activities have the effect of limiting an invasive species. In such cases, the interaction between humans and their natural habitat is mutualistic, i.e., one of reciprocal benefits, but such a relationship cannot be incorporated into the PSR framework. And yet it appears just as important that we identify the interaction indicators that make it possible to monitor uses representing pressure as those representing opportunities for biodiversity (symbiosis) or those that simply have no substantial impact on biodiversity (commensalisms) to imagine genuine possibilities for the reconciliation of development goals and conservation goals. This is why it is more useful to speak in terms of "forces" than in terms of "pressure," as the system may be subject to forces caused by human activity that may be either positive or negative.

\section{Response Indicators}

Traditionally, response indicators are the percentage of protected areas or the existence of parks. In the case of our study, the classic institutional responses, therefore, already existed. Thus, it was suggested that we propose alternative responses. The representatives of the local populations mentioned responses that are linked to their vulnerability: professional material that will make it possible to produce more or confer added value to products by transforming them; equipment, such as drills for access to water, or road infrastructures for access to markets. Responses that more specifically concern conflicts were also mentioned: processes of conciliation and clarification of access and use rights; organization of watering points along transhumance (seasonal livestock migration) routes. Two opposing trends appeared among the reserve managers. The first group recommended radical solutions, such as killing the entire herd if it is caught inside the central zone of the biosphere reserve, in the hopes of stopping incursions by transhumant stock breeders. The second group, taking a participatory management approach, recommended setting up co-management policies. Both groups emphasized the need for infrastructure, equipment, and training in order to move around, improve communication between control stations, and ensure biodiversity monitoring and better control access to the core areas. Lastly, the representatives of conservation programs put forward numerous solutions for the 
Table 3. Representatives and groups met during the diagnostic phase.

\begin{tabular}{|c|c|c|c|}
\hline Mare aux Hippopotames & $\mathrm{W}$ & Boucle du Baoulé & Niokolo Koba \\
\hline $\begin{array}{l}\text { Social and natural } \\
\text { scientists }\end{array}$ & $\begin{array}{l}\text { Social and natural } \\
\text { scientists }\end{array}$ & Social and natural scientists & Social and natural scientists \\
\hline Reserve managers & Reserve managers & Reserve managers & Reserve managers \\
\hline $\begin{array}{l}\text { President of the Balla } \\
\text { fishers' group }\end{array}$ & $\begin{array}{l}\text { Moli beekeepers } \\
\text { committee }\end{array}$ & $\begin{array}{l}\text { Representatives of the } \\
\text { sedentary Wani livestock } \\
\text { breeders }\end{array}$ & $\begin{array}{l}\text { Representatives of the } \\
\text { Médinacouta community (in } \\
\text { particular, banana growers) }\end{array}$ \\
\hline $\begin{array}{l}\text { President of the } \\
\text { professional livestock } \\
\text { breeders' group }\end{array}$ & $\begin{array}{l}\text { Representatives of the } \\
\text { Tapoa guides' association }\end{array}$ & $\begin{array}{l}\text { Representatives of the Wani } \\
\text { vegetable growers }\end{array}$ & $\begin{array}{l}\text { The Friends of the Nature (non- } \\
\text { governmental organization) }\end{array}$ \\
\hline $\begin{array}{l}\text { Representatives of the } \\
\text { Balla farmers' group }\end{array}$ & $\begin{array}{l}\text { Representatives of the } \\
\text { Tamou community (in } \\
\text { particular, livestock } \\
\text { breeders) }\end{array}$ & $\begin{array}{l}\text { Representatives of the Missira } \\
\text { beekeepers }\end{array}$ & $\begin{array}{l}\text { President of the Dialakoto } \\
\text { women's group }\end{array}$ \\
\hline \multirow[t]{7}{*}{$\begin{array}{l}\text { President of the Balla } \\
\text { women's group }\end{array}$} & $\begin{array}{l}\text { Representatives of the } \\
\text { Allambaré community (in } \\
\text { particular, farmers) }\end{array}$ & $\begin{array}{l}\text { The Didjeni hunters' } \\
\text { association }\end{array}$ & $\begin{array}{l}\text { Representatives of the Wassadou } \\
\text { community (in particular, banana } \\
\text { growers) }\end{array}$ \\
\hline & $\begin{array}{l}\text { Representatives of the } \\
\text { Karey-Kopto community } \\
\text { (in particular, managers } \\
\text { of a tourist camp) }\end{array}$ & $\begin{array}{l}\text { The Tiokombougou women's } \\
\text { group }\end{array}$ & $\begin{array}{l}\text { Representative of the AGIR } \\
\text { conservation program }\end{array}$ \\
\hline & $\begin{array}{l}\text { Representatives of the } \\
\text { Boumba community (in } \\
\text { particular, fishers) }\end{array}$ & $\begin{array}{l}\text { Representatives of the } \\
\text { transhumant Fulani livestock } \\
\text { breeders from Dioumara }\end{array}$ & $\begin{array}{l}\text { Representatives of the Borassus } \\
\text { palm tree growers }\end{array}$ \\
\hline & $\begin{array}{l}\text { Representatives of the } \\
\text { Tondey community (in } \\
\text { particular, hunters) }\end{array}$ & $\begin{array}{l}\text { Representatives of the } \\
\text { Sebekoro farmers }\end{array}$ & $\begin{array}{l}\text { Chief of a bananas perimeter in } \\
\text { Médinacouta }\end{array}$ \\
\hline & & $\begin{array}{l}\text { Representatives of the Minian } \\
\text { artisan }\end{array}$ & $\begin{array}{l}\text { President of the Médinacouta } \\
\text { fishers' group }\end{array}$ \\
\hline & & $\begin{array}{l}\text { Representatives of somonos } \\
\text { fishers from Missira }\end{array}$ & $\begin{array}{l}\text { Representatives of the } \\
\text { Médinacouta women's group }\end{array}$ \\
\hline & & & $\begin{array}{l}\text { Representative of the Serere } \\
\text { farmers (who do not cultivate } \\
\text { bananas) }\end{array}$ \\
\hline
\end{tabular}

erosion of biodiversity at these sites. Among them: developing ecotourism, using improved-efficiency fireplaces to reduce firewood consumption, using natural fertilizers to improve production without causing pollution, using fodder to relieve pressure on pasture lands. Responses tended to vary according to the category of stakeholders making the suggestion. Whereas for the local populations, the solutions to biodiversity erosion involve developing production capacities and access to markets, for reserve managers they are rather a matter of monitoring capacity and, depending on the situation, the managers' leeway to penalize or to negotiate. Lastly, the conservation programs seek 
an intermediate solution that aims at reconciling development objectives with conservation objectives.

The wide range of proposed solutions makes it possible to highlight the political nature of this category of indicators. Thus, response indicators are necessarily the result of long and complex negotiation. Response indicators will be useful for reserve managers only if they are linked to indicators giving information about individual and collective response capacities, but also about the effectiveness of these responses. To a large degree, individual response capacities are linked to the population's dependency with regard to biodiversity. Collective response capacities refer to institutional and organizational capacities. This is, in particular, a matter of identifying the indicators that make it possible to assess the local population's capacity to take responsibility for managing the resources on which they depend. Finally, response effectiveness is largely a function of the legitimacy of the process that led to the adoption of responses. These different factors are determined by numerous economic parameters (financial, human, and organizational resources), as well as social parameters (political will upstream, the nature of local social relations, conflicting interests, the status of stakeholders, institutions for access, and existing uses), all of which make the identification of response indicators extremely difficult to implement.

\section{PSR Indicators and Representation of the Social-Ecological Interactions}

Existing interaction indicators can be classified according to representations of the interactions between development and conservation issues (Adams et al. 2004). If conservation and development are considered as parallel issues, PSR indicators can be used because development is only a source of pressure (urbanization, overexploitation...) or response (kuznet curve) (1). If development is considered to be a primary constraint to achieving some conservation outputs (and to avoid poaching, for instance) PSR indicators could also be used, but should be complemented by local development indicators (2). If development is considered to be a duty requiring that the costs and benefits due to conservation policies be equitably distributed, PSR indicators could again be used, but should be articulated by cost and benefit indicators as well as income distribution indicators (3). Finally, if conservation of biodiversity is considered as sustainable development, some indicators of sustainable use of ecosystem services should be included. In such a case, PSR indicators are clearly not suited (4). This last anthropocentric approach is not apprpriate in a biosphere reserve where the core zone needs to be protected from human activities. On the other hand, it might be interesting to develop indicators in the buffer and transition zones, where people are completely dependent on their natural environment, as is the case in developing countries.

\section{Proposing a New Framework for Identifying Interaction Indicators}

Based on the above points, we suggest adapting the Millennium Ecosystem Assessment framework to develop an alternative conceptual framework that might enable a different organization of interaction indicators for managing biodiversity (Fig. 2), and selecting interaction indicators from stakeholders' perceptions.

Thus, during the diagnostic phase, participants would be asked to designate, on a voluntary basis, a representative who would act as their spokesperson during an indicator co-construction session to take place over the following days. It must be clearly understood that these representatives will be required to report back to their home villages and to the groups they represent (hunters, fishers, stock breeders, etc.).

The choice of representatives is based on several criteria initially suggested by the UNESCO-MAB/ UNEP-GEF programme. Those involved should be: representative of the activities taking place in the biosphere reserve; representative of the villages located in the biosphere reserve (for most of them, in the transition areas); and representative of lowstatus groups (usually neglected) (Table 4).

Finally, these initial encounters make it possible to identify several potential mediators to carry out the co-construction process. They are selected based on their legitimacy in the eyes of local populations as well as reserve managers, but also taking into account the institution they come from and their local mediation experience. One of the objectives is to have two mediators who do not belong to the same institutions, to ensure a degree of self-control. 
Fig. 2. PSR-MEA diagram to select interaction indicators.

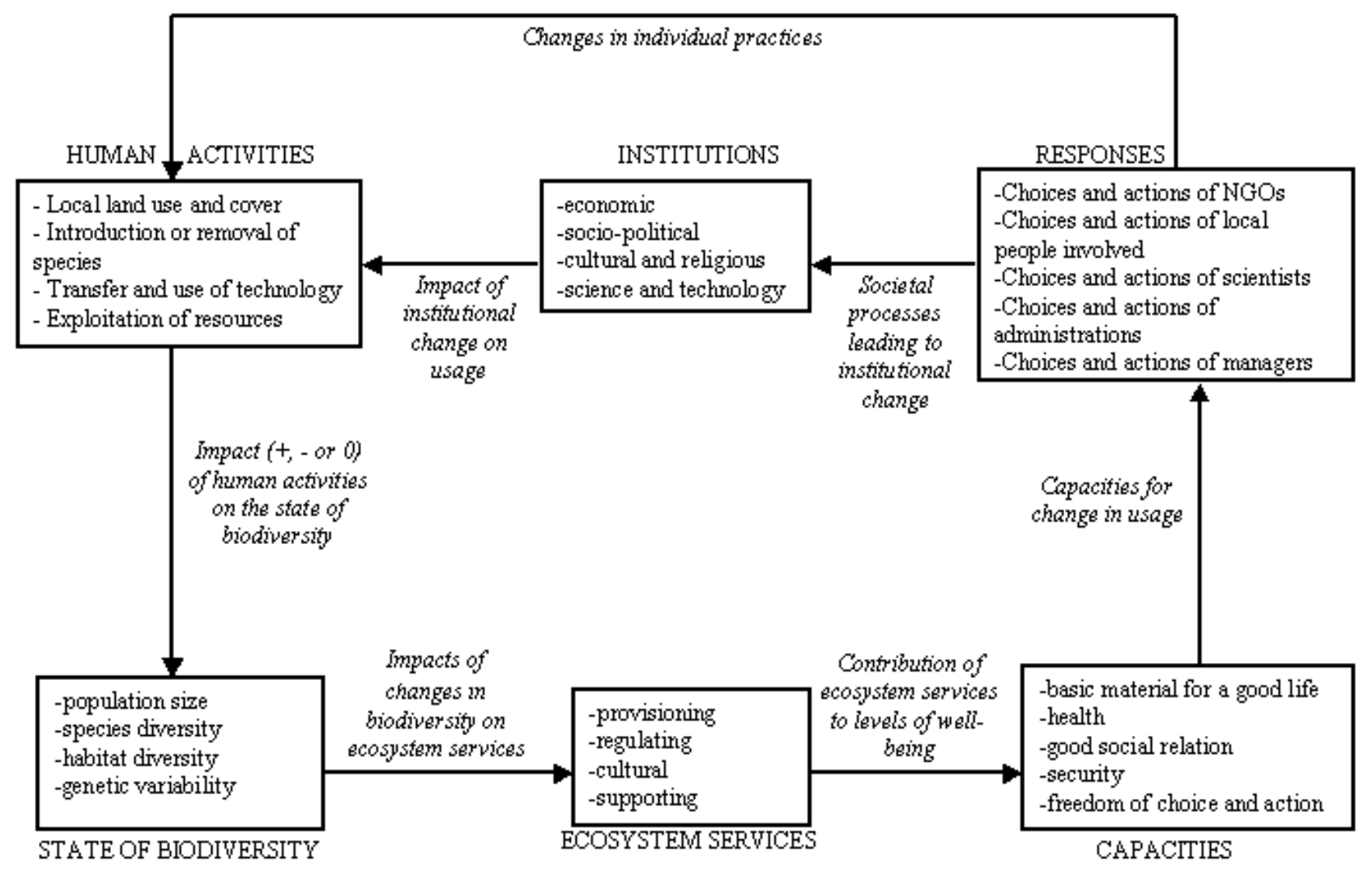

\section{RESULTS CONCERNING THE CO- CONSTRUCTION PHASE: A TESTING EXPERIENCE FOR DEVELOPING INTERACTION INDICATORS FROM INDIVIDUAL PERCEPTIONS}

Robert Costanza and Matthias Ruth (1998) have highlighted the importance of developing some user-friendly models that would permit consensus building across, and not only within, fields, and also between scientists and local stakeholders. A stepby-step approach is particularly adapted to developing such tools. Indeed, they suggest beginning with highly general models involving stakeholder representation that are based on collective consensus. The use of graphical support is particularly adapted at this point. The second step requires providing fine details about social and ecological processes that express how the socialecological system works. Finally, lternative scenarios must be proposed based on various management options in order to favor collective learning-by-doing processes. This three-step approach has been retained in order to: contextualize the social-ecological systems of the biosphere reserves (step 1); identify the interaction indicators issuing from the storytelling (step 2); and launch simulations concerning alternative scenarios (step 3). 
Table 4. Communities of practice who participated in the co-construction processes (one $\mathrm{X}=$ one representative).

\begin{tabular}{|c|c|c|c|c|}
\hline & $\begin{array}{c}\text { Mare aux } \\
\text { Hippopotames }\end{array}$ & $\mathrm{W}$ & Boucle du Baoulé & Niokolo Koba \\
\hline Ecologists & $\mathrm{X}$ & $\mathrm{X}$ & $\mathrm{X}$ & $\mathrm{X}$ \\
\hline Social scientists & $\mathrm{X}$ & & & \\
\hline Facilitators & $\mathrm{XX}$ & $\mathrm{XX}$ & $\mathrm{XX}$ & $\mathrm{XX}$ \\
\hline Breeders & $X$ & $X$ & & \\
\hline $\begin{array}{l}\text { Transhumant livestock } \\
\text { breeders }\end{array}$ & & & $\mathrm{X}$ & \\
\hline $\begin{array}{l}\text { Sedentary livestock } \\
\text { breeders }\end{array}$ & & & $\mathrm{X}$ & \\
\hline Farmers & & $\mathrm{X}$ & $\mathrm{X}$ & $\mathrm{XXX}$ \\
\hline Vegetable growers & & & $\mathrm{X}$ & \\
\hline Women & $\mathrm{XX}$ & $\mathrm{XX}$ & $\mathrm{XX}$ & $\mathrm{XX}$ \\
\hline Hunters & $\mathrm{X}$ & $\mathrm{XX}$ & $\mathrm{X}$ & \\
\hline Gatherers & $X$ & & & \\
\hline Forest resource users & $\mathrm{X}$ & & & $\mathrm{X}$ \\
\hline $\begin{array}{l}\text { Borassus palm tree } \\
\text { growers }\end{array}$ & & & & $\mathrm{X}$ \\
\hline Beekeepers & & $\mathrm{X}$ & $\mathrm{X}$ & \\
\hline $\begin{array}{l}\text { Professionals, tourism } \\
\text { industry }\end{array}$ & & $\mathrm{XX}$ & & \\
\hline $\begin{array}{l}\text { Representatives of the } \\
\text { local communities }\end{array}$ & $\mathrm{XX}$ & $\mathrm{X}$ & $\mathrm{XX}$ & $\mathrm{X}$ \\
\hline Artisans & & & $\mathrm{X}$ & \\
\hline Fishers & $\mathrm{XX}$ & $\mathrm{XX}$ & $\mathrm{X}$ & $\mathrm{X}$ \\
\hline Park agents & $\mathrm{XX}$ & $\mathrm{XX}$ & XXXX & $\mathrm{X}$ \\
\hline Environmental NGO & & & & $\mathrm{X}$ \\
\hline
\end{tabular}




\section{The Co-construction Phase}

The co-construction phase, which lasts 3-4 days, consists of bringing together local stakeholder representatives (10-15 people), two scientists who are familiar with the area under study (one from the social sciences and the other from the natural sciences), one or two reserve managers, and the two local mediators (Table 4). The co-construction process consists of a certain number of rules that will make it possible to organize the work of producing indicators. The objective is to respect diverse perceptions and viewpoints while seeking to create a common language that aims at coordinating these viewpoints.

The scientists' main role is to help participants when they need specific information, in particular in the event of disagreement or to verify a particular point. Their role is also to organize the information that is provided. They must not, however, intervene directly in negotiation processes or during collective choices. This position is based on the assumption that difference in status and knowledge between scientists and the local stakeholders could inhibit the collective discussion.

The mediators' primary duties are to record the discussion results on a chart, to generate a climate of trust, and to offset power struggles during the negotiation processes. They must also act as translators, as participants do not all speak the same local language.

The co-construction method must be simple and pragmatic, for the mediators face various difficulties during the co-construction process and it is constantly necessary to adapt their methods (Table 5). There is no point in talking about "indicators" or "biodiversity", concepts that have no real concrete meaning for participants. Instead, discussion should focus on resources, relationships, signs, and practices. Work is organized in steps, based on simple questions inspired by the Integrated Natural Resource Management approach (Lal et al. 2001) and by earlier work conducted in the Pendjari Biosphere Reserve in May 2003 (UNESCO 2003, Etienne 2006).

The aim of the first five questions is to contextualize interaction indicators within a specific socialecological system:

- Which stakeholders use the reserve's natural resources to meet their needs?
- Who are the six main stakeholders on the list?

- What relationships exist among these stakeholders regarding the reserve's resources?

- What are the reserve's resources for each of these stakeholders?

- What relationships exist among these resources?

The final four questions allow us to identify concrete and simple interaction indicators from stakeholders' viewpoints:

- How do stakeholders procure, collect, and/or make use of these resources?

- On the basis of what information, criteria, and constraints do stakeholders make decisions concerning their activities? (This rather broad formulation aims at identifying what we call "criteria for action." They represent the factors that give structure to individual actions. These parameters may be connected to information, institutions, social interactions, needs, etc.)

- What do they do with these resources?

- What signs reveal that resources are more abundant or more scarce in the reserve?

This session is based on collective discussion for the first five questions (1) and storytelling for the last four questions (2).

These questions are designed to initiate and stimulate discussion about the use of ecosystem services and related information. They represent a base that the mediators worked from, according to language, context, how the project evolved, and the participants' interest. The order in which issues were addressed, the form they took, and the level of detail varied from one site to another.

To address these issues, participants break into two working groups. The mediators monitor the groups to ensure that everyone is participating and that the issues have been fully grasped. Next, a collective reporting session takes place for participants. 
Table 5. Problems and solutions adopted during the co-construction sessions.

\begin{tabular}{|c|c|}
\hline Difficulties & Means of resolving it \\
\hline $\begin{array}{l}\text { Problem describing the social-ecological system } \\
\text { starting from natural resources }\end{array}$ & Description started from stakeholders \\
\hline $\begin{array}{l}\text { Problem distinguishing "direct stakeholders" from } \\
\text { "indirect stakeholders" }\end{array}$ & This point was abandoned \\
\hline $\begin{array}{l}\text { Distances are too great to achieve geographical } \\
\text { representativeness (e.g., Boucle du Baoulé) }\end{array}$ & $\begin{array}{l}\text { Representativeness of areas where co-construction was launched with } \\
\text { regard to what has happened over the entire biosphere reserve }\end{array}$ \\
\hline $\begin{array}{l}\text { Language problem (different languages in the } \\
\text { same place and a high level of illiteracy) }\end{array}$ & Use of diagrams (with icons and arrows) and maps \\
\hline Problem working on social-ecological interactions & $\begin{array}{l}\text { Co-construction is achieved through a step-by-step process and the } \\
\text { system description was based on stakeholders' stories and points of } \\
\text { view }\end{array}$ \\
\hline $\begin{array}{l}\text { Large number of interactions led to complexity } \\
\text { and cognition problems }\end{array}$ & $\begin{array}{l}\text { Participants had to select the six most important agents in order to } \\
\text { indirectly restrict the number of social-ecological interactions } \\
\text { (described from stakeholders' stories) }\end{array}$ \\
\hline $\begin{array}{l}\text { Social-ecological interactions issue in biosphere } \\
\text { reserves was too vast to create interest }\end{array}$ & $\begin{array}{l}\text { After describing social-ecological interactions, participants had to } \\
\text { choose one specific issue that was important to them. Then, a new } \\
\text { phase of description was initiated to collectively resolve this common } \\
\text { question }\end{array}$ \\
\hline $\begin{array}{l}\text { Too much time allowed to describe activities and } \\
\text { decisions criteria (sometimes } 8 \mathrm{~h} \text { ) vis-à-vis the rest } \\
\text { of the co-construction process }\end{array}$ & $\begin{array}{l}\text { During description of the stakeholders' activities, mediators asked } \\
\text { participants why stakeholders made this kind of choice, why they used } \\
\text { this tool... It helped decrease the time taken to describe the activity }\end{array}$ \\
\hline $\begin{array}{l}\text { Problems initiating sense-making simulations } \\
\text { containing accurate information }\end{array}$ & Use of role-playing game \\
\hline Lack of data & $\begin{array}{l}\text { Development of simple protocols that allow collection, organization, } \\
\text { and standardization of local knowledge }\end{array}$ \\
\hline
\end{tabular}

\section{Collective Discussion and Description of a Social-Ecological System}

For describing the social-ecological system, participants exchange viewpoints and negotiate, in the event of disagreement, about the choice of stakeholders, resources, or interactions. Discussions continue until participants reach a consensus. Trade-offs are facilitated by the use of mediation tools (diagrams, maps of the reserve, icons, figurines, arrows) that make it possible, little by little, to illustrate the results of discussions. If consensus is not possible, the mediators take into account the different perceptions for the next step. The mediators take part in the discussions in order to organize the debate and underline possible redistribution of the groups-in order to limit the number of parameters to be taken into account - to avoid use of terms that have no concrete meaning or to identify inconsistencies in the descriptions. They regulate how much time each participant may take on floor to ensure that each person may express his or her opinion about the topics under discussion. Once the group has decided on the stakeholders (Table 6), resources (Table 7), and interactions, the mediators summarize the results and list them on a chart (Fig. 3). This allows a gradual description of the system of stakeholder-biodiversity interactions and offers an overall view of results. 
Table 6. Stakeholders selected by the participants during the co-construction processes.

\begin{tabular}{|c|c|c|c|c|}
\hline & Mare aux Hippopotames & $\mathrm{W}$ & Boucle du Baoulé & Niokolo Koba \\
\hline Farmer & & $\mathrm{X}$ & $\mathrm{X}$ & $\mathrm{X}$ \\
\hline Vegetable grower & & & $\mathrm{X}$ & \\
\hline Stock breeder & $\mathrm{X}$ & $\mathrm{X}$ & $\mathrm{X}$ & $\mathrm{X}$ \\
\hline Forest resource user & $\mathrm{X}$ & $\mathrm{X}$ & $\mathrm{X}$ & $\mathrm{X}$ \\
\hline Gatherer & & & & $\mathrm{X}$ \\
\hline Fisher & $\mathrm{X}$ & $\mathrm{X}$ & $\mathrm{X}$ & $\mathrm{X}$ \\
\hline Weaver & & $\mathrm{X}$ & & \\
\hline Hunter & $\mathrm{X}$ & $\mathrm{X}$ & $\mathrm{X}$ & \\
\hline Park agent & & & & $\mathrm{X}$ \\
\hline Blacksmith & & $\mathrm{X}$ & $\mathrm{X}$ & $\mathrm{X}$ \\
\hline Woman & $\mathrm{X}$ & & & \\
\hline Beekeeper & $\mathrm{X}$ & $\mathrm{X}$ & $\mathrm{X}$ & \\
\hline Wart hog & & & & $\mathrm{X}$ \\
\hline Cynocephalus (baboo) & & & & $\mathrm{X}$ \\
\hline
\end{tabular}

\section{Identification of Interaction Indicators from a Storytelling Perspective}

Mental modeling allows people to anticipate future events and make decisions in light of them. In order to build such mental models, people need information about their environment. This information is perceived through identified signals given out through everyday activities. Such signals can be considered as simple sense-making indicators, which then provide an interesting support to improve collective negotiations.

Through storytelling, the representative of a particular practice draws a description of its activities. This description is then completed by other participants, and a new negotiation process begins. Mediators use this assessment in order to identify implicit indicators used by stakeholders. These implicit indicators can be split into two categories: "use indicators" and "decision criteria indicators" (Append. 1).

Use indicators are identified from the answer to the question "How do stakeholders procure, collect, and/or make use of these resources?" These use indicators facilitate precise description of the practices, and go over simple pressure indicators. They reflect "what do they" as well as "how they do it."

Decision criteria indicators are selected from the answer to the questions "On the basis of what information, criteria, and constraints do stakeholders make decisions concerning their activities?" and "What do they do with these resources?" The decision criteria indicators improve understanding of why stakeholders do or do not do something, why they make that specific choice, and what sense such an action has. These indicators allow us to monitor 
Table 7. Resources selected by the participants during the co-construction processes.

\begin{tabular}{|c|c|c|c|c|}
\hline & $\begin{array}{c}\text { Mare aux } \\
\text { Hippopotames }\end{array}$ & $\mathrm{W}$ & Boucle du Baoulé & Niokolo Koba \\
\hline Water & $\mathrm{X}$ & $\mathrm{X}$ & $\mathrm{X}$ & \\
\hline River Water & & & & $X$ \\
\hline Rain Water & & & & $\mathrm{X}$ \\
\hline Clay & & $\mathrm{X}$ & & $\mathrm{X}$ \\
\hline Wetland & & & $\mathrm{X}$ & \\
\hline Productive lands & & $\mathrm{X}$ & $X$ & $\mathrm{X}$ \\
\hline Grass & $\mathrm{X}$ & $\mathrm{X}$ & $\mathrm{X}$ & $\mathrm{X}$ \\
\hline Wildlife & $\mathrm{X}$ & $\mathrm{X}$ & $\mathrm{X}$ & \\
\hline Livestock & & $\mathrm{X}$ & & \\
\hline Tree & & $\mathrm{X}$ & $X$ & $X$ \\
\hline Borassus palm tree & & & & $\mathrm{X}$ \\
\hline Wood & & $\mathrm{X}$ & & \\
\hline Deadwood & $\mathrm{X}$ & & & \\
\hline Fruits of the forest & $\mathrm{X}$ & & & \\
\hline Bee & $\mathrm{X}$ & $\mathrm{X}$ & & \\
\hline Honey & & & $\mathrm{X}$ & \\
\hline Bamboo & & & $\mathrm{X}$ & $\mathrm{X}$ \\
\hline Mound & & & $\mathrm{X}$ & \\
\hline Fish & $\mathrm{X}$ & $\mathrm{X}$ & $\mathrm{X}$ & $\mathrm{X}$ \\
\hline Manure & & & & $\mathrm{X}$ \\
\hline
\end{tabular}

the essential driving forces that are the very source of human practices and to better understand what are the main incentives for people when making a choice.

When discussing uses and criteria for decisions, participants seek to show the diversity of the practices and techniques connected to their activities, or to justify this or that use. This step in co-construction in fact gives them an opportunity to explain to the other participants - and to the reserve managers in particular - what they do, and why and how they do it, and to show that their activities may not be simply considered as a form of "pressure."

The decision-making criteria include motivations (finding food, warmth), technical limitations (lack of means for more intensive farming, lack of means of transport), ecological limitations (scarcity of certain resources, lack of water), regulatory 
Fig. 3. The co-construction process of the social-ecological system.

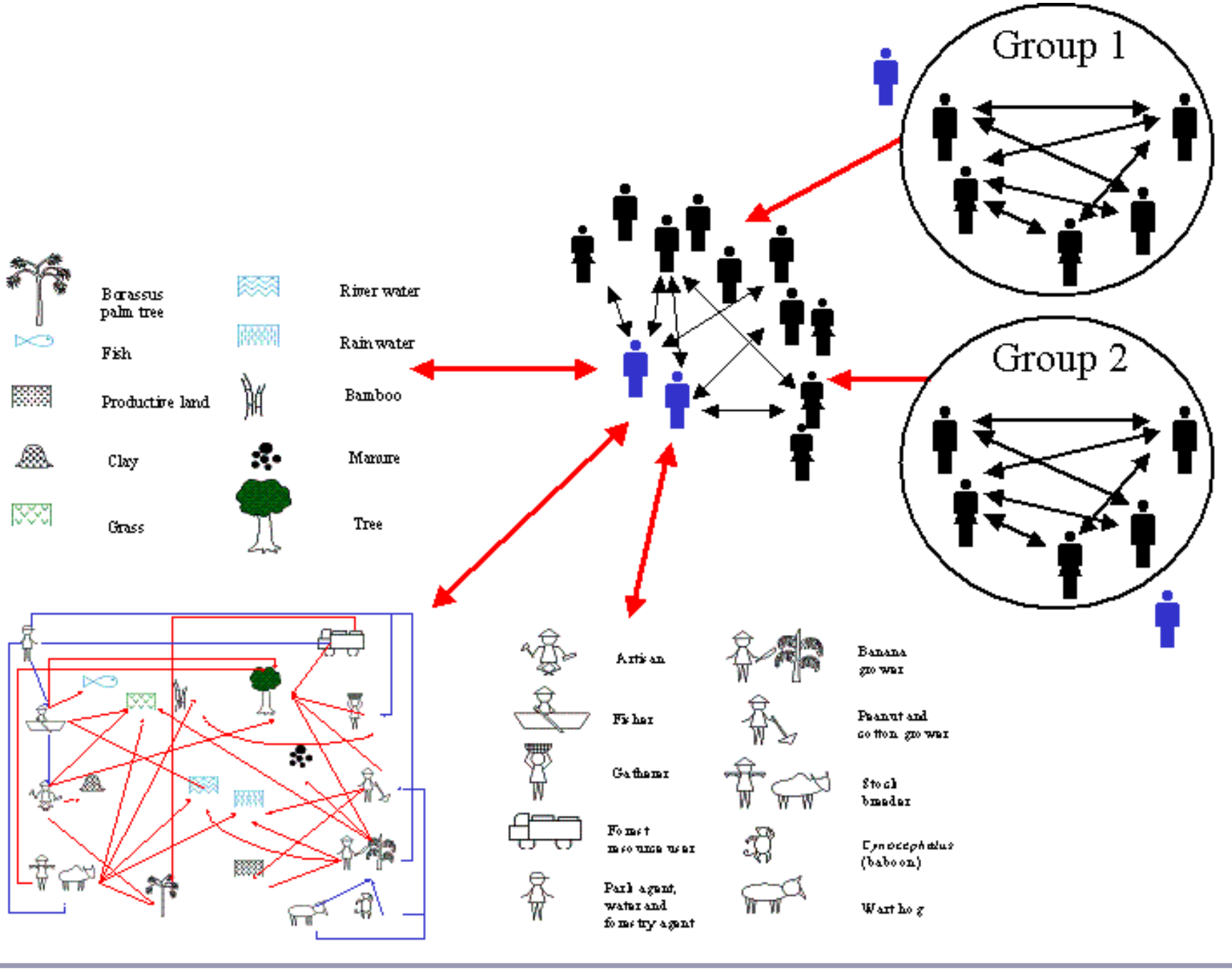

constraints (boundaries of the natural reserve, size of mesh for netting), incentives (price, demand, risk), conventions (transhumance routes they have "always" used), institutions (extensive livestock breeding among the Peuls, sacred forests), rules of behavior (eating habits), representations (planting banana trees as a source of profit).

These are indicators that stakeholders use in a more or less conscious way when making decisions about their activities. These indicators refer to the "capacities" available to them, and which concern the use of resources, but also possible adaptive responses. These capacities are mainly linked to acting institutions and state of ecosystem services (Table 8). If such capacity is limited (selfconsumption, lack of substitution techniques, no alternative resources), it is difficult to change practices without offering new opportunities to the concerned stakeholders. Such indicators make it possible to underline the fact that implementing conservation policies and identifying the corresponding response indicators requires companion policies for local development to be taken into account.

These details provide valuable information for those who would like to communicate about biodiversity 
Table 8. Ecosystem services, use, and decision criteria indicators identified from local knowledge (useful for beekeepers, fishers, and hunters).

\begin{tabular}{|c|c|c|c|}
\hline $\begin{array}{l}\text { Stakeholders } \\
\text { (resources) }\end{array}$ & $\begin{array}{l}\text { Indicators of changing } \\
\text { ecosystem services }\end{array}$ & Use indicators & Decision criteria indicators \\
\hline $\begin{array}{l}\text { Beekeeper } \\
\text { (bees) }\end{array}$ & $\begin{array}{l}\text { - number of hives } \\
\text { - size of swarms } \\
\text { - rainfall } \\
\text { - speed/ time it takes for the } \\
\text { bees to fill the hives with } \\
\text { honey } \\
\text { - change in the number } \\
\text { of modern hives / traditional } \\
\text { hives }\end{array}$ & $\begin{array}{l}\text { - number of beekeepers } \\
\text { - number of hives observed on } \\
\text { trees } \\
-\% \text { of modern hives / traditional } \\
\text { hives } \\
\text { - honey production } \\
\text { - number of associations of honey } \\
\text { producers } \\
\text { - material available to process and } \\
\text { package honey }\end{array}$ & $\begin{array}{l}\text { - ease with which a hive can be colonized } \\
\text { - ease with which a hive can be } \\
\text { constructed } \\
\text { - ease of honey collection } \\
\text { - cost of the hive } \\
\text { - desired quality of honey } \\
\text { - demand for honey } \\
\text { - price of honey } \\
\text { - availability of sites that meet } \\
\text { requirements for installing a beehive }\end{array}$ \\
\hline $\begin{array}{l}\text { Fisher } \\
\text { (fish) }\end{array}$ & $\begin{array}{l}\text { - change in price of fish } \\
\text { - water abundance } \\
\text { - rainfall } \\
\text { - number of fishers on the } \\
\text { water } \\
\text { - changing embankment } \\
\text { areas, } \\
\text { - scarcity of "flagship" } \\
\text { species (sold and } \\
\text { consumed) } \\
\text { - increase or decrease in } \\
\text { amount of banned materials }\end{array}$ & $\begin{array}{l}\text { - number of fishers } \\
\text { - number of catches } \\
\text { - species caught } \\
\text { - size of fish caught } \\
\text { - number of dugout canoes on the } \\
\text { water } \\
\text { - number of nets in the water } \\
\text { - number of inventoried nets, hoop } \\
\text { nets, dugout canoes } \\
\text { - number of fishers' associations }\end{array}$ & $\begin{array}{l}\text { - need of fish for food } \\
\text { - need of fish to pay taxes, pay for } \\
\text { ceremonies } \\
\text { - lack of alternative resources } \\
\text { - seasons (low /high waters) } \\
\text { - species sought } \\
\text { - water currents } \\
\text { - available material } \\
\text { - water level } \\
\text { - park limits } \\
\text { - fines imposed by foresters } \\
\text { - prices offered by major traders } \\
\text { - price of fishing material } \\
\text { - regulations concerning net / mesh sizes } \\
\text { - regulations concerning protected species }\end{array}$ \\
\hline $\begin{array}{l}\text { Hunter } \\
\text { (game) }\end{array}$ & $\begin{array}{l}\text { - changing meat prices } \\
\text { - rainfall } \\
\text { - change in number of } \\
\text { domestic animals, } \\
\text { appearance of epizootic } \\
\text { diseases (especially for } \\
\text { buffalo) } \\
\text { - easy observation of } \\
\text { 'flagship' species } \\
\text { (hartebeest, cheetah, } \\
\text { sassaby, elephant...) } \\
\text { - animal calls, cries } \\
\text { - flight initiation distance } \\
\text { - quantity of traces / prints } \\
\text { and recent droppings }\end{array}$ & $\begin{array}{l}\text { - number of observed carcasses } \\
\text { - number of cartridges found } \\
\text { - number of observed hunting } \\
\text { camps } \\
\text { - number of fines/tickets } \\
\text { - number of observed hunting } \\
\text { systems } \\
\text { - respect for traditional hunting } \\
\text { rules } \\
\text { - number of poachers observed } \\
\text { (by guides in particular) when } \\
\text { moving from place to place }\end{array}$ & $\begin{array}{l}\text { - need for food } \\
\text { - abundance of game outside the core area } \\
\text { - alternative resources } \\
\text { - limits of the core area } \\
\text { - eating habits } \\
\text { - orders from major traders } \\
\text { - traditional hunting rules } \\
\text { - price of meat } \\
\text { - habits } \\
\text { - available material } \\
\text { - fines (number and cost) }\end{array}$ \\
\hline
\end{tabular}


conservation and prompt a change in uses. In particular, they make it possible to identify the sense-making indicators that need to be adjusted or developed in order to observe real changes in system dynamics.

Indicators concerning ecosystem services were addressed on the basis of signs of evolving resources perceived by stakeholders as they carry out their activities ("What signs reveal that resources are more abundant or more scarce in the reserve?"). Most of the time, local stakeholders are in fact entirely dependent on the resources surrounding them and keep track of various signs that provide information about any changes to such resources (Append. 1). Therefore, they have specific information about the evolution of a given resource (Moller et al. 2004). Some of these signs indicate non-viable use (number of truckloads of wood headed for towns, intensive techniques), whereas others are indirect signs (such as species that indicate soil fertility) or direct signs (flight initiation distance, the time it takes for a beehive to fill). All these signs provide ecosystem services monitoring indicators that are both simple and relevant for local populations. For the participants, they translate into negative or positive trends concerning their future and their children's future, and thus relate to sustainability indicators (Table 8).

Based on use indicators, synthetic indicators of capacity and sustainability were developed (Table 9, Fig. 4).

\section{Simulations from Interaction Indicators}

The co-construction process also involved evaluating in what ways these indicators would make it possible to better comprehend socialecological interactions, and therefore, to better apportion the co-evolution processes between social systems and ecological systems, in such a way as to then be able to use them as a tool to facilitate discussions about the uses of biodiversity. In order to do this, simulations were carried out the last day of the co-construction process (except for the Mare aux Hippopotames because of time constraints), based on interaction indicators and mediation tools. Simulations are based on "what if" scenarios proposed by the participants in order to make the indicators more dynamic, or, shall we say, more "lively." Four types of tools are used for this: interaction matrices, diagrams composed of icons and arrows, geographic maps, and role-playing games. Such simulations make it possible for the indicators corresponding to the participants' descriptions to co-evolve. Thus, it is possible to test the coherence of interactions, to identify elements that may have been overlooked, to define the appropriate time step, and to fine-tune the interaction parameters. (The time step concerns the way in which one looks at the system's evolution. An adequate time step thus corresponds to the most significant time scales to understand how the system under study evolves: season, year, day, or even the period of transhumance represent examples of time steps that may appear adequate for understanding the evolution of activity-biodiversity interactions in the biosphere reserves.)

The success of such simulations is directly linked to the mediation tools that are used (Table 10). The use of interaction matrices did not yield useful results due to the complexity created by the large number of parameters, retroactive effects that were difficult to grasp, and the use of nouns and verbs that were often hard to express in a non-written way. The diagrams provided a way to communicate more easily, but did not make it possible to convey much information. Role playing turned out to be the most effective means of carrying out simulations (Bousquet et al. 2002, Gurung et al. 2006). It stimulated a great deal of interest among participants, with very strong participation and long impassioned discussions.

When simulations were based on matrices or graphics, these representations were produced by the mediator. When simulations were based on role playing, the mediator simply organized them. In the first case, participants take a "command and control" approach to indicators, making it possible to describe or "pilot" a system. In the second case, they are in a system and interact with it through the use of indicators (Levrel et al. 2006). The simulation is itself the result of choices made by the players during the game. These choices have an impact on individual indicators (income, yields, time available, investment, etc.), but also on the collective indicators that each player uses (e.g., availability of wood or of water). This type of simulation is useful because participants become individual users of the indicators they previously created, which offers them a unique opportunity to appropriate these indicators. In such a way, the players can directly observe the impact of their uses, 
Table 9. Synthetic indicators of capacity and sustainability for fishing and hunting.

\begin{tabular}{llll}
\hline \hline Activities & Use indicators & Indicators of sustainability of use & $\begin{array}{l}\text { Indicators of capacity for changing } \\
\text { use practices }\end{array}$ \\
\hline Fishing & $\begin{array}{l}\text { - abundance and diversity } \\
\text { of catches / fisher / time of } \\
\text { day }\end{array}$ & $\begin{array}{l}\text { - number of traditional fishers / } \\
\text { number of professional fishers }\end{array}$ & $\begin{array}{l}\text { - existence of local access and use } \\
\text { rules and their effectiveness } \\
\text { - resources from fishing / total } \\
\text { resources }\end{array}$ \\
Hunting & $\begin{array}{l}\text { - abundance and diversity } \\
\text { of catches / hunter / hunt } \\
\text { - number of signs of } \\
\text { poaching (cartridges, } \\
\text { hunting camps, flight } \\
\text { initiation distance, etc.) per } \\
\text { hectare }\end{array}$ & $\begin{array}{l}\text { - level of external demand: tourists, } \\
\text { major 'foreign' traders, ... (estimated } \\
\text { number of exported items) }\end{array}$ & $\begin{array}{l}\text { - resources from hunting / total } \\
\text { resources } \\
\text { - existence of traditional hunting rules } \\
\text { and their effectiveness }\end{array}$ \\
& & & \begin{tabular}{l} 
\\
\hline
\end{tabular}
\end{tabular}

social interactions, certain rules of biodiversity dynamics, or of the retroactive effects that occur.

By taking indicator-based decisions, they capture them and realize they need new indicators to carry out their game plan. The connection between indicator refinement and decision making enables players to become aware of the direct and indirect interactions - social and ecological - on which they and the surrounding resources depend, but also to adapt their behavior (individually or collectively) in order to deal with these changes. They provide an opportunity to begin repeated processes of individual and collective learning about societynature interactions. In fact, role playing makes it possible to link ecological, social, and economic dynamics to individual decisions that have an impact on parameters concerning various players, which sooner or later prompt participants to begin collective discussions with the goal of proposing and negotiating solutions to deal with these collective problems. These negotiation processes imply comparing the arguments of the various parties who use the co-constructed indicators to justify this or that viewpoint. The process makes it possible to gradually identify the key or structural indicators that determine, to a large extent, the dynamics of the society-nature system. Lastly, role playing gives managers and scientists an experimental tool to work on the indicators, as it allows them to observe how the indicators are used as a tool for communication and decision making: those that make the most "sense" for the players when they make choices concerning their activities or when they adapt their practices; those that will be mobilized during collective debates to justify a viewpoint or an action; and, lastly, those that seem to be the most legitimate for all parties-all of this being necessary information to ensure better communication among stakeholders within the biosphere reserves.

Therefore, although indicators represent a traditional tool for centralized planning and expertise, related most of the time to a "command and control" approach, role playing offers an opportunity to use the indicators in an interactive, decentralized way at a local scale.

\section{PROSPECTS}

\section{Feedbacks}

In order to assess how well the new interaction indicators resulting from the co-construction process fulfil their function, they must be evaluated to assess the degree of usefulness assigned to them by the various stakeholders, and in what way they can provide tools to support dialog. We captured the reactions of local stakeholders (including reserve managers) during the co-construction process. We captured scientists' main objections and criticisms as well as their positive reactions during the 
Fig. 4. PSR-MEA diagram to select interaction indicators for hunting.

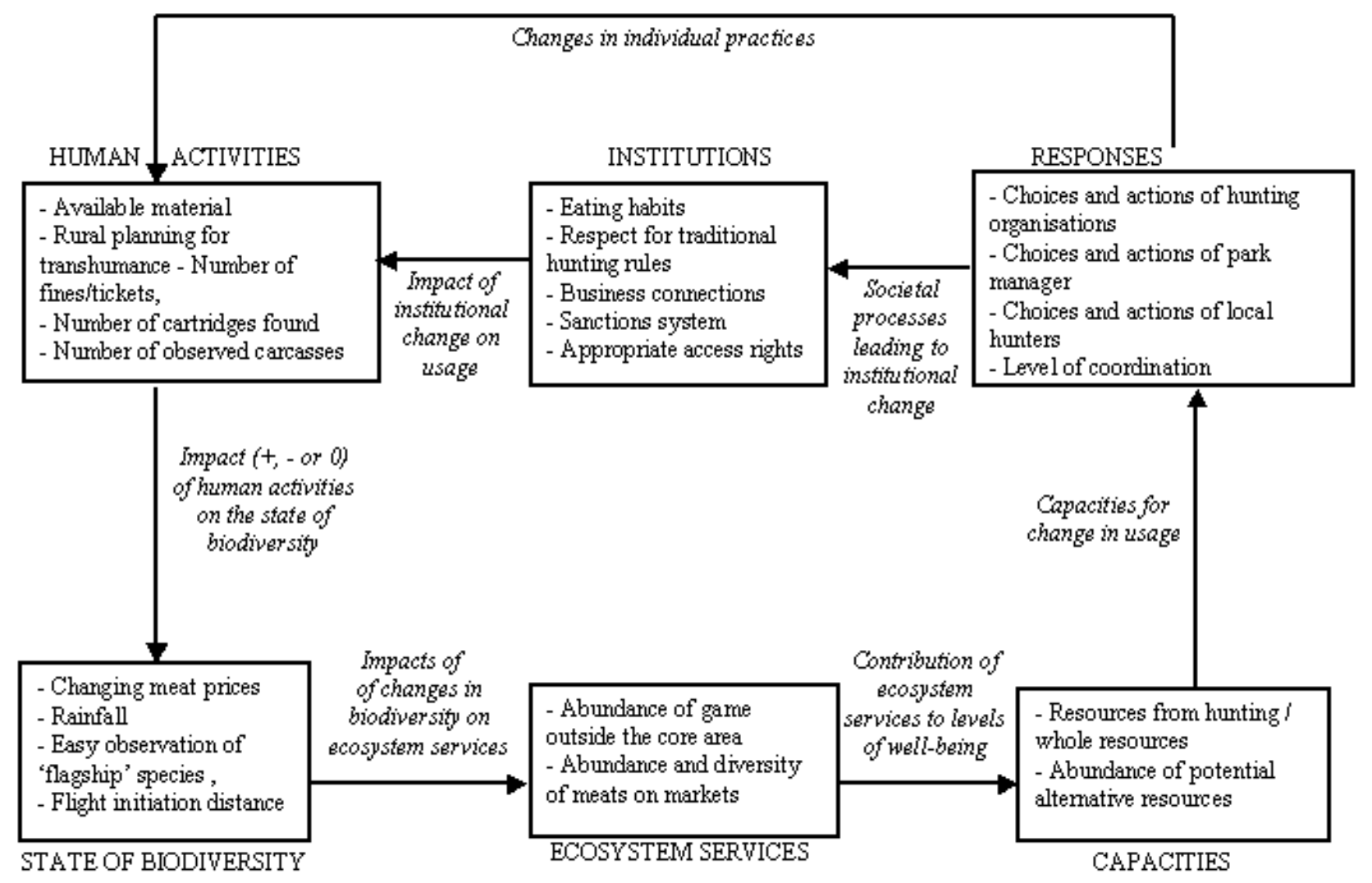

collective discussion raised by the presentation of interaction indicators (specifically, a communication carried out at Bamako after the local co-construction process and another one carried out in a UNESCOMAB/UNEP-GEF workshop (UNESCO 2005)). Although these reactions have not been precisely quantified and analyzed through direct interviews, the main reactions to the indicators can be summarized as follows (Table 11).

Scientists from a natural science background mainly criticized the biodiversity monitoring indicators, which were addressed through signs of changing resources as perceived by local populations. The scientists felt that this type of information was not as reliable as when classical methods of ecological monitoring are used, for example, based on transects. Moreover, the "utilitarian" ecosystem services approach raised questions for the ecologist who worked on biodiversity (e.g., is it necessary that biodiversity have an economic value for it to be deemed worthy of monitoring?). However, these scientists appreciated the description of stakeholders' individual behaviors because the use indicators provided a better understanding of the stakeholders' strategies, as well as new arguments for conservation (linking conservation and well-being issues). 
Table 10. Mediation tools used to create interaction indicators dynamics.

\begin{tabular}{|c|c|c|c|c|}
\hline & Matrices of interaction & $\begin{array}{l}\text { Diagrams with icons and } \\
\text { arrows }\end{array}$ & Geographic maps & Role-Playing Game \\
\hline $\begin{array}{l}\text { Reserve where tool } \\
\text { has been tested }\end{array}$ & $\mathrm{W}$ & $\begin{array}{l}\text { Boucle du Baoulé and } \\
\text { du Niokolo Koba }\end{array}$ & $\begin{array}{l}\text { Boucle du Baoulé and } \\
\text { Niokolo Koba }\end{array}$ & Niokolo Koba \\
\hline Pro & $\begin{array}{l}\text { Helps support complex } \\
\text { information concerning } \\
\text { interactions }\end{array}$ & $\begin{array}{l}\text { Helps communicate vis- } \\
\text { à-vis interactions }\end{array}$ & $\begin{array}{l}\text { Helps support spatial } \\
\text { representations (area } \\
\text { of the reserves...) }\end{array}$ & $\begin{array}{l}\text { Helps initiate } \\
\text { interactive and } \\
\text { collective learning } \\
\text { processes }\end{array}$ \\
\hline Cons & $\begin{array}{l}\text { Lack of relevance for } \\
\text { local stakeholders }\end{array}$ & Lack of information & Lack of interactions & $\begin{array}{l}\text { Lack of scientific } \\
\text { status }\end{array}$ \\
\hline $\begin{array}{l}\text { Efficiency in } \\
\text { initiating discussions } \\
\text { about interactions }\end{array}$ & Weak & Medium & Medium & Strong \\
\hline
\end{tabular}

Scientists from a social science background criticized the use indicators for being reductionistic, especially those related to the stakeholders' criteria for action; thus the stakeholders' behaviors cannot be summarized in a truly satisfactory way using these indicators. However, they liked the way it was possible to identify biodiversity indicators based on individual perceptions and to envisage monitoring protocols based on local knowledge. Indeed, the originality of this approach lies in the use of traditional technical monitoring methods.

The reserve managers had positive reactions about the signs and uses, the former providing them with valuable information about the state of biodiversity, and the latter enabling them to better grasp the stakeholders' use strategies. In both cases, they can provide reserve managers with very effective tools for communicating with local stakeholders. However, they do not really capture how to implement the changing services indicators through standardized protocols.

Representatives of local populations were interested in the use and monitoring indicators because they represent indicators that had been identified based on their personal experience, and that focus on the ecosystem services. They manifested a degree of concern, however, about the way in which reserve managers could actually make use of them (risk of strategic behavior to better control the population's activities).

Actually, the identification of interaction indicators is based on a very simple method. This approach has been well-perceived by scientists providing it did not concern their own discipline. Indeed, the ecologist could not possibly consider the signs of ecosystem services trends as biodiversity indicators. This perspective is not standardized enough and does not capture the intrinsic significance of what biodiversity is. For their part, the social scientists (mostly ethnologists) considered that it was impossible to understand individual behavior from simple "use" indicators: stakeholder behaviors are too complex to be captured by indicators. However, these indicators appear to be valuable for the local stakeholders and the reserve managers. Such reactions highlight how difficult it is for scientists to abandon even a small part of their disciplinary axioms and how going beyond established boundaries can develop sensemaking interaction indicators that can be used for adaptive co-management. 
Table 11. Reactions to the new indicators.

\begin{tabular}{lcc}
\hline \hline $\begin{array}{l}\text { Indicators } \\
\text { Participants }\end{array}$ & Indicators of changing ecosystem services* & Use and decision criteria indicators* \\
\hline Local population & +++ & ++ \\
Park manager & ++ & +++ \\
Social scientist & +++ & + \\
Natural scientist & + & +++
\end{tabular}

*The number of "+" relates to the degree of satisfaction expressed by participants when the "state of biodiversity indicators" and the "use indicators" were detailed in restitutions.

+- this type of indicator is not reliable for managing social-ecological interactions

++- this type of indicator provides an effective tool for managing social-ecological interactions, but raises some questions about implementing them

+++- this type of indicator provides an original new tool for managing social-ecological interactions

\section{Limitations to the Co-construction Process}

Although mediators have partly governed social interactions in order to create a fair process, the problem of power relationships still has an impact on the co-construction process. Such power relationships depend on many parameters. Five can be highlighted:

The first is the ability to speak French. Indeed, although the discussion was carried in the local language, participants used French for addressing scientists and park managers who were more at ease with it. This was definitely an advantage for the participants. This trend appears quite counterproductive to creating a fair process because those who did not understand French distrusted the process.

The second parameter points out the importance of literacy. It is very clear that an illiterate person has low symbolic status throughout the discussions taking place in the workshops. Moreover, even if the socioecological system was mostly described through icons and arrows, there were words written on the board.

The third is the ability to have some kind of relationship with scientists and park managers. For instance, tour guides feel at ease with scientists, mediators, or park managers, but this is not necessarily the case for other local stakeholders.

Another point deals with the nature of the activities engaged in by stakeholders. Indeed, some participants were engaged in illegal activities, such as poaching, and it was very difficult for them to trust the process and to actively take part in the debates. The same problem of participation affected women, who were not very active in three of the four reserves (the exception being in the Mare aux Hippopotames).

The final problem deals with the attitude of the park managers. Most of the time, they respected the principles of neutrality. However, in one of the biosphere reserves, they criticized the representatives. This was very counterproductive for the coconstruction process. In fact, these criticisms have led to changes in the implicit rules of the games, stipulating that all participants should be equal. Moreover, this created mistrust of the way in which interaction indicators will be used (concertation vs. control). Such criticisms arose where park managers were the most numerous. Thus, it is clear that the number of representatives plays a significant role in the co-construction process. 
All these points showed how interaction indicators partly resulted from such power relationships.

Therefore, an absolute prerequisite for having an efficient and legitimate process is the presence of legitimate mediators who are able to calm struggles during shifts in the balance of power that occur during dialog. In addition, a common charter (e.g., the ethical charter developed by the ComMod group (http://cormas.cirad.fr/ComMod/fr/charter/content. $\underline{\mathrm{htm}}$ )) could be useful in order to reinforce the rules of the game in the co-construction process.

One concern would be to identify which main stakeholders should be retained through the coconstruction process in order to make it the most efficient (in term of adaptive co-management). At this point, the necessity of coordination at the "activity level" (bringing together hunters, fishers, beekeepers...) could be debated. It might be more efficient to organize the co-construction process around a specific activity. For example, it might appear of utmost importance to improve coordination between professional and traditional fishers concerning the specific management of the fisheries, whereas intending to improve discussion between fishers, hunters and other local representatives concerning the management of social-ecological interaction in general appears minor. A preliminary investigation on the level at which the main conflicts in the biosphere reserve occur could be useful in order to improve this point.

\section{How to Implement New Interaction Indicators?}

The operational quality of the interaction indicators drawn from this co-construction exercise is linked to the selection of a limited number of indicators and to the availability of data that would permit their implementation.

To begin with, working group participants select, among the identified indicators, those that seem most useful for local stakeholders, as well as those that will enable them to satisfy their need for information concerning specific problems.

Secondly, access to information is necessary. This information should help with monitoring the indicators and defining the parameters of existing interactions among the various selected indicators. Such information implies a cost for its collection, processing, and maintenance. To reduce these costs, it is possible to reach an agreement with resource users and set up simple protocols to collect information during the activity itself (Moller et al. 2004, Levrel 2006).

Such processes exist already, especially with tour guides who gather information while moving from place to place. However, it is necessary making such practices widespread by applying them to fishing, apiculture, gathering activities, and so on. Once this information has been collected, it should be reviewed by the scientists and/or reserve managers, then reported in different forms to the stakeholders who practice the activities and are affected by resource monitoring.

By way of example, once a month simple information could be collected about fishing by those who carry out this activity (date, fishing spot, material used, number of species caught, number of fish caught, time spent on the water, number of fishers near the boat) to then produce indicators of value for both the fisher and the reserve manager (number of fish caught depending on what material was used, number of species depending on the site, productivity per hour and by site, anthropogenic pressure per site, species diversity, population size). This should enable local populations to better appropriate the indicators developed from this information and provide a basis for discussing issues of ecosystem services use.

This, however, requires the presence of a resource person "on the ground" to centralize, organize, and report the information. The current coordinator is a scientist who lives in the capital remote from the field study. He cannot adequately perform his function because he does not live near the biosphere reserve. However, local mediators could perform this function. In particular, a coordinator should, be able to provide the means for users to collect this information, and maintain ties with the population, scientists, and reserve managers in order to create a climate of trust among the different parties. A coordinator should be responsible for distributing information and for managing a network within which the information could be enhanced and used by all, and must receive training about organizing and processing information. Moreover, a coodinator must be provided with the means (a salary and some materials) to develop, implement, and run such an information system. However, for the moment, there are no prospects for releasing it because the 
UNESCO-MAB/PNUE-GEF programme's constraints did not allow pursuit of the experiment until now, and this international program will end in late 2007.

\section{CONCLUSION}

The process of co-constructing interaction indicators represented an opportunity to initiate dialog dynamics among stakeholders who, quite often, are not used to communicating with one another.

With respect to the interaction indicators, it became clear that a desire to classify the indicators based on a pressure-state-response model did not fulfil the objective of improving communication among the stakeholders. In fact, identifying sources of pressure and response involves identifying those responsible for them and taking measures that will be adopted to the detriment of certain categories of stakeholders. For this reason, establishing pressure and response indicators will have a tendency to exacerbate conflicts rather than facilitate discussion.

Thanks to a collective process of negotiation, making choices, and ranking priorities, all participants were gradually able to formalize the social-ecological interactions present in the biosphere reserves. This process also provided an opportunity to produce indicators that make sense to all the stakeholders and which, moreover, enjoy a certain legitimacy.

Identifying interaction indicators based on a detailed description of the stakeholders' perceptions and uses, and putting the accent on local stakeholders' capacity to change their use practices or make adaptive responses to various types of change that affect them seems to offer interesting prospects for improving communication among stakeholders about biodiversity use and access, and for its sustainable management.

In the same vein, this work demonstrated the possibility of developing simple evaluation tools at a low cost (in terms of time, money, and human relationships). This is very important in developing countries where human, technical, and financial resources are lacking for improving monitoring systems regarding both the state of biodiversity and human uses.
Responses to this article can be read online at:

http://www.ecologyandsociety.org/voll3/iss 1/art28/responses/

\section{Acknowledgments:}

We wish to thank: the coordinators Karimou Ambouta, Lamine Kane, Mahamane Maiga, and Jeanne Millogo-Rasolodimby; the local mediators Abdulaye Altine, Zonyé Blagna, Kombi Arhidio Boubacar, Abdulaye Diallo, Victor Goulane, and Bou Koné; all the participants in the coconstruction experiments; and the two anonymous reviewers for their valuable comments. The authors' research case studies were funded by the UNESCOMAB (Man And Biosphere)/UNEP (United Nations Environment Programme) - GEF (Global Environment Fund) Regional Project on "Building scientific and technical capacity for effective management and sustainable use of biodiversity in dryland biosphere reserves of West Africa."

\section{LITERATURE CITED}

Adams, W., R. Aveling, D. Brockington, B. Dickson, J. Elliot, J. Hutton, D. Roe, B. Vira, and W. Wolmer. 2004. Biodiversity conservation and the eradication of poverty. Science 306:1146-1149.

Arias, E. G., and G. Fischer. 2000. Boundary objects: their role in articulating the task at hand and making information relevant to it. International ICSP Symposium on Interactive and Collaborative Computing, December 2000. 8 p.

Arrow, K. J., G. Daily, P. Dasgupta, S. Levin, K. G. Mäler, E. Maskin, D. Starrett, T. Sterner, and T. Tietenberg. 2000. Managing ecosystem resources. Environmental Science and Technology 34(8):1401-1406.

Berkes, F., and C. Folke. 2002. Back to the future: ecosystem dynamics and local knowledge. Pages 121-146 in L. H. Gunderson, and C. S. Holling, editors. Panarchy. Understanding transformations in human and natural systems. Island Press, Washington, D.C., USA.

Berkes, F., and C. Folke, editors. 1998. Linking social and ecological systems: management practices and social mechanisms for building 
resilience. Cambridge University Press, Cambridge, UK.

Bousquet, F., O. Barreteau, P. D'Aquino, M. Etienne, S. Boissau, S. Aubert, C. Le Page, D. Babin, and J. C. Castella. 2002. Multi-agent systems and role games: collective learning processes for ecosystem management. Pages 248286 in M. A. Janssen, editor. Complexity and ecosystem management. The theory and practice of multi-agent systems. Edward Elgar, London, UK.

Bowker, G., and S. L. Star. 1999. Sorting things out. Classification and its consequences. MIT Press, Cambridge, Massachusetts, USA.

Briassoulis, H. 2001. Sustainable development and its indicators: through a (planner's)glass darkly. Journal of Environmental Planning and Management 44(3):409-427.

Callon, M., P. Lascoumes, and Y. Barthe. 2001. Agir dans un monde incertain. Essai sur la démocratie technique. Seuil, collection La couleur des idées, Paris, France.

Commission on Sustainable Development. 1992. Agenda 21. [online] URL: http://www.un.org/esa/s ustdev/agenda21.htm.

Commission on Sustainable Development. 2001. Indicators of sustainable development: guidelines and methodologies. Division for Sustainable Development, United Nations, New York, New York, USA.

Costanza, R., and M. Ruth. 1998. Using dynamic modeling to scope environmental problems and build consensus. Environmental Management 22:183-195.

Desrosières, A. 2003. Les qualités des quantités. Courrier des statistiques 105-106:51-63.

Dietz T., E. Ostrom, and P. C. Stern. 2003. The struggle to govern the commons. Science $\mathbf{3 0 2}$ (5652):1907-1912.

Espeland, W. N., and M. L. Stevens. 1998. Commensuration as a social process. Annual Review of Sociology 24:313-343.

Etienne, M. 2006. Companion modelling: a tool for dialogue and concertation in biosphere reserves.
Pages 44-52 in M. Bouamrane, editor. 2006. Biodiversity and stakeholders: concertation itinaries. UNESCO Edition, Paris, France.

European Environment Agency (EEA). 2003. Europe's environment: the third assessment. EEA, Copenhagen, Denmark.

Folke, C. 2004. Traditional knowledge in socialecological systems. Ecology and Society 9(3): 7. http//www.ecologyandsociety.org/vol9/iss3/art7/.

Gunderson, L. H., S. R. Carpenter, C. Folke, P. Olsson, and G. D. Peterson. 2006. Water RATs (resilience, adaptability, and transformability) in lake and wetland social-ecological systems. Ecology and Society 11(1): 16. http://www.ecology andsociety.org/vol11/iss1/art16/.

Gunderson, L. H., and C. S. Holling, editors. 2002. Panarchy. Understanding transformations in human and natural systems. Island Press, Washington, D.C., USA.

Gunderson, L. H., C. S. Holling, and S. S. Light, editors. 1995. Barriers and bridges to the renewal of ecosystems and institutions. Columbia University Press, New York, New York, USA.

Gurung, T. R., F. Bousquet, and G. Trébuil. 2006. Companion modeling, conflict resolution, and institution building: sharing irrigation water in the Lingmuteychu Watershed, Bhutan. Ecology and Society 11(2): 36 . http://www.ecologyandsociety.org/ vol11/iss2/art36/.

Holling, C. S. 1978. Adaptive environmental assessment and management. Wiley, London, UK.

Hukkinen, J. 2003. From groundless universalism to grounded generalism: improving ecological economic indicators of human-environmental interaction. Ecological Economics 44:11-27.

Kinzig, A., D. Starrett, K. Arrow, S. Aniyar, B. Bolin, P. Dasgupta, P. Ehrlich, C. Folke, M. Hanemann, G. Heal, M. Hoel, A. M. Jansson, B.O. Jansson, N. Kautsky, S. Levin, J. Lubchenco, K.-G. Mäler, S. W. Pacala, S. H. Schneider, D. Siniscalco, and B. Walker. 2003. Coping with uncertainty: a call for a new science-policy forum. AMBIO: A Journal of Human Environment 32 (5):330-335. 
Lal, P., H. Lim-Applegate, and M. C. Scoccimarro. 2001. The adaptive decision-making process as a tool for integrated natural resource management: focus, attitudes, and approach. Conservation Ecology 5(2): 11. http://www.ecolog yandsociety.org/vol5/iss2/art11/.

Lee, K. N. 1999. Appraising adaptive management. Ecology and Society 3(2): 3. http://www.ecologyan dsociety.org/vol3/iss2/art3/.

Levrel, H. 2004a. Rapport du travail de coconstruction des indicateurs d'interactions à la Réserve de Biosphère de la Mare aux Hippopotames. Renforcement des capacités scientifiques et techniques pour une gestion effective et une utilisation durable de la diversité biologique dans six réserves de biosphère d'Afrique de l'ouest. Projet régional UNESCO-MAB/UNEP-GEF. (online) URL: http://www.unesco.org/mab/project/savannas/ RapportcoconstructionBurkina.pdf.

Levrel, H. 2004b. Rapport du travail de coconstruction des indicateurs d'interactions à la Réserve de Biosphère du W. Renforcement des capacités scientifiques et techniques pour une gestion effective et une utilisation durable de la diversité biologique dans six réserves de biosphère d'Afrique de l'ouest. Projet régional UNESCOMAB/UNEP-GEF. http://www.unesco.org/mab/project/ savannas/RapportcoconstructionNiger.pdf.

Levrel, H. 2004c. Rapport du travail de coconstruction des indicateurs d'interactions à la Réserve de Biosphère de la Boucle du Baoulé. Renforcement des capacités scientifiques et techniques pour une gestion effective et une utilisation durable de la diversité biologique dans six réserves de biosphère d'Afrique de l'ouest. Projet régional UNESCO-MAB/UNEP-GEF. http:/ /www.unesco.org/mab/project/savannas/

RapportcoconstructionMali.pdf.

Levrel, H. 2006. Construire des indicateurs durables à partir d'un savoir issu de multiples pratiques : le cas de la biodiversité. Annales des Mines - Série Gérer et Comprendre 85:51-62.

Levrel, H., M. Bouamrane, and L. Kane.2006. La co-construction de systèmes d'information sur les interactions entre développement humain et conservation de la biodiversité : l'exemple d'un programme MAB mené dans la Réserve de Biosphère du Niokolo-Koba. Pages 164-195 in V.
Reboud, editor. Amartya Sen : Un économiste du développement? AFD Editions, Paris, France.

Levrel, H., M. Etienne, C. Kerbiriou, C. Le Page, and M. Rouan. Co-modeling process, negotiations and power relationships: some outputs from a MAB project in the island of Ouessant. Society and Natural Resources: In press.

Levrel, H., and L. Kane. 2005. Rapport du travail de co-construction des indicateurs d'interactions à la Réserve de Biosphère du Niokolo Koba. Renforcement des capacités scientifiques et techniques pour une gestion effective et une utilisation durable de la diversité biologique dans six réserves de biosphère d'Afrique de l'ouest. Projet régional UNESCO-MAB/UNEP-GEF. http:/ /www.unesco.org/mab/project/savannas/

RapportFinalNiokoloAvril2005.pdf.

May, P. 1992. Policy learning and policy failure. Journal of Public Policy 12:331-354.

Millennium Ecosystem Assessment. 2005. Ecosystem and human well-being: synthesis. Island Press, Washington, D.C., USA.

Moller, H., F. Berkes, P. O'Brian Lyver, and M. Kislalioglu. 2004. Combining science and traditional ecological knowledge: monitoring populations for co-management. Ecology and Society 9(3): 2. http://www.ecologyandsociety.org/ vol9/iss3/art2/.

Olsson, P., C. Folke, and F. Berkes. 2004. Adaptive co-management for building resilience in socialecological systems. Environmental Management 34:75-90.

Organisation for Economic Co-operation and Development (OECD). 1994. Environmental indicators. OECD core sets. OECD, Paris, France.

Ostrom, E., R. Gardner, and J. Walker. 1994. Rules, games, and common-pool resources. University of Michigan Press, Ann Arbor, Michigan, USA.

Ostrom, E. 1990. Governing the commons. Cambridge University Press, Cambridge, UK.

Pretty, J. 1995. Participatory learning for sustainable agriculture. World Development 23 (8):1247-1263. 
Pretty, J. 2003. Social capital and collective management of resources. Science 302(5652):19121916.

Rouwette, E., J. Vennix, and T. van Mullekom. 2002. Group model building effectiveness: a review of assessment studies. System Dynamics Review $\mathbf{1 8}$ (1):5-45.

UNESCO. 2003. Projet Régional UNESCO-MAB/ $P N U E-F E M$. Atelier de formation régional sur le dialogue et la concertation dans les réserves de biosphère d'Afrique de l'Ouest. Réserve de biosphère de la Pendjari, Bénin, 11-17 May 2003. Final report. UNESCO, Paris, France.

UNESCO. 2005. Projet régional UNESCO-MAB/ $P N U E-F E M$. Rapport final de la réunion de l'atelier technique régional. Réserve de biosphère du Niokolo Koba, Sénégal, 21-24 February 2005. Final report. UNESCO, Paris, France.

United Nations Environment Programme, Convention on Biological Diversity. 2003. Report of Expert Meeting on Indicators of Biological Diversity Including Indicators for Rapid Assessment of Inland Water Ecosystems. 10-14 November 2003, Montreal, Quebec, Canada.

Vennix, J. 1996. Group model-building: facilitating team learning using system dynamics. Wiley, Chichester, UK.

Vennix, J. 1999. Group model-building: tackling messy problems. System Dynamics Review $\mathbf{1 5}$ (4):379-401.

Walters, C. J., and R. Hilborn. 1978. Ecological optimisation and adaptive management. Annual Review of Ecology and Systematics 9:157-188.

Weber, J. 1996. A gestão de recursos renovaveis : fundamentos téoricos de um programa de pesquisas. Pages 115-146 in P. F. Veira and J. Weber, editors. Gestão de recursos renovaveis e desenvolvimento. Cortez editora, São Paolo, Brazil.

Westley, F., S. R. Carpenter, W. A. Brock, C. S. Holling, and L. H. Gunderson. 2002. Why systems of people and nature are not just social and ecological systems. Pages 103-119 in L. H. Gunderson and C. S. Holling, editors. Panarchy. Understanding transformations in human and natural systems. Island Press, Washington, D.C., USA. 
Appendix 1. Identification of interaction indicators from the co-construction process: example of the Niokolo-Koba Biosphere Reserve 